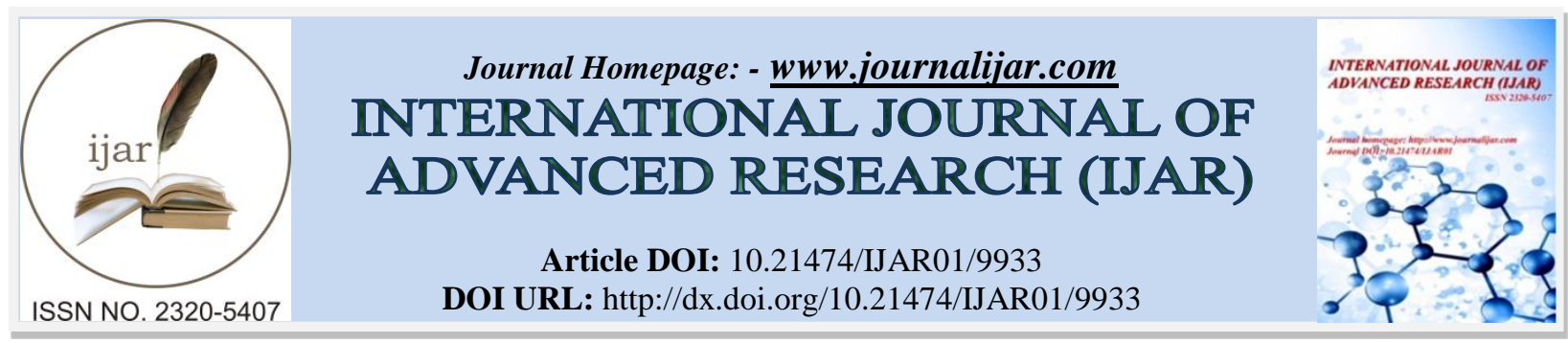

RESEARCH ARTICLE

\title{
ENHANCEMENT OF CASSAVA FERMENTATION USING NAIL AND SCENT LEAF (OCCIMUM VIRIDIS).
}

Udensi J.U. ${ }^{1}$, Ebe T. ${ }^{1}$, Ugochukwu G.M. ${ }^{2}$, Awurum I.N. ${ }^{2}$, Mgbemena I. C. ${ }^{3}$, Aroh K ${ }^{3}$ and Ezenweani, E ${ }^{3}$.

1. Department of Environmetal Health Science, Federal University of Technology Owerri.

2. Department of Health Biology, Alvan Ikoku Federal College of Education Owerri.

3. Department of Biotechnology, Federal University of Technology Owerri.

\section{Manuscript Info}

\section{Manuscript History}

Received: 18 August 2019

Final Accepted: 20 September 2019

Published: October 2019

Key words:-

Cassava, Fermentation, Additives, Retting, Cyanide content.

\begin{abstract}
The effects of two additives (nails and scent leaf) in cassava fermentation process were studied using standard microbiological and physiochemical methods. Fresh cassava roots were harvested; about $200 \mathrm{~g}$ of the cassava roots were fermented with $3.0 \mathrm{~g}$ of scent leaf and 2 pieces of three inches nails separately, while the control was fermented without any additive, all for 4days. The steep water and retting cassava were collected daily from the scent leaf (Occimum viridis), nail and control containers for the laboratory analysis. The microbiological analysis revealed the presence of the following isolates, Bacillus spp, Streptococcus spp, Proteus spp, Pseudomonas spp, Aspergillus spp, Lactobacillus spp, Candida spp and Saccharomyces spp. The pH values of all the samples decreased gradually over the 4 days of fermentation, with statistical significant difference $(p<0.05)$ in the values obtained at different days but no statistical significant difference ( $p>0.05$ ) in $\mathrm{pH}$ change for different additives. Cyanide concentration of the fermenting water increased from 0.31 to $3.4 \mathrm{mg} / \mathrm{ml}, 0.28$ to $3.02 \mathrm{mg} / \mathrm{ml}$ and 0.27 to $1.33 \mathrm{mg} / \mathrm{ml}$ for nail, scent leaf and control respectively during the fermentation period. There was statistical significant difference $(\mathrm{p}<0.05)$ in the reduction level of cyanide with different additives at different days. The use of scent leaf to enhance cassava fermentation should be encouraged since it has higher fermentation rate, recorded lesser residual cyanide with increased protein contents thereby improving food quality.
\end{abstract}

Copy Right, IJAR, 2019,. All rights reserved.

\section{Introduction:-}

Cassava processed into fufu or garri is one of the major staple foods consumed in most Eastern part of Nigeria. Fermentation has remained a method adopted in detoxifying the cyanide contents of the cassava as well as improving the nutritional values. In a bid to enhance fermentation, different types of additives ranging from nails, scent leaf, kerosene, detergents, to beans have been used by many people.

Cassava (Manihot esculenta) woody shrub belongs to the Euphorbiaceae family grown for its edible tubers for major carbohydrate source (Offor., 2011). Cassava amongst its composition contains several anti-nutritional substances and elements toxic to health, these elements include the cyanogenic glucosides such as linamarin $(96 \%$ of total

Corresponding Author:- Udensi, J.U.

Address:- Department of Environmetal Health Science, Federal University of Technology Owerri. 
cyanogenic content), lataustralin (Methyl Linamarin, 4\%) and the enzyme Linamarase (Montagnac, Davis \& Tanumihardjo, 2009; Milena et al., 2013). The enzyme linamarase catalyses linamarin hydrolysis to glucose and acetone cyanohydrin while it hydrolyses Lotaustralin to related cyanohydrins and glucose. The acetone cyanohydrin catalysed by alpha-hydroxynitrile lyase (HNL) furthermore decomposes to acetone and hydrogen $\mathrm{cyanide}$ at $\mathrm{pH}$ above 5 and temperature of $30^{\circ} \mathrm{C}$ (Montagnac,2009, Tivana, 2012).

Hydrogen cyanide, residual linamarin and its respective acetone cyanohydrin when not properly removed from cassava during processing causes severe health effects like Goitre, Cretinism and death due to cyanide poisoning (Kobawila, 2005). Basically two varieties of cassava with differing cyanide content exist which are the bitter and sweet. The low cyanogens (sweet) cassava are utilized with minor processing while the high cyanogen (bitter) variety are processed widely before consumption (Sayre, 2011).

Processing of Cassava is very essential as it lowers these detrimental cyanogenic glycosides and performs the function of preservation; it also generates other products having varied characteristics from Cassava (Salami et al., 2011). Cassava processing for food production is influenced by resources, customs and preferences present in the locality, such methods include boiling of the roots, sun drying and fermentation (Kobawila, 2005, Siritunga et al., 2011).

Fermentation converts sugars and other carbohydrates found in Cassava to useful end products, enhances the texture, flavour, digestibility, decreases need for cooking (and fuel) and improves shelf-life through formation of lactic acid, acetic acid and alcohol that deter spoilage microorganisms (Aro, 2008; Egwim et al., 2013). Fermentation is one of the cheapest means of performing the dual function of nutrient enrichment with protein, essential amino acids, fatty acids and vitamins to the cassava, as well as detoxifying the anti-nutrients, thus enhancing the food quality (Aro, 2008; Binin, 2014). Locally available cassava foods produced via subjection to fermentation microorganisms and enzymes include garri, fufu and lafun (Etudaiye et al., 2009; Salami et al., 2011).

Fermentation depends on the type of substrate (cassava), micro flora and environmental factors to soften the cassava tissues, leading to the enzyme linamarase (present in the cell wall) action on the cyanogenic glucosides, linamarin and lotaustralin leading to the generation of glucose and acetone cyanohydrins immediately disintegrated to hydrocyanic acid (HCN) and acetone under anaerobic conditions (Aworh, 2008; Eleazu et al, 2011).

The purpose of this study was to compare the effectiveness of enhancing cassava fermentation using nail and scent leaf. This was achieved through the identification of the microorganisms involved in cassava fermentation, determination of the effects of nail as an additive on cyanide content of fermenting cassava, determining the effects of scent leaf as an additive on cyanide content of fermenting cassava and on the rate of fermentation and finally establishing if the agents have any effect on the nutritional values of the cassava.

\section{Materials and methods:- Sample preparations \\ Scent Leaf}

Fresh scent leaves were obtained from Ihiagwa market square, Owerri West L.G.A., Imo State. It was spread on a tray and dried in an oven at $65^{\circ} \mathrm{C}$ for $48 \mathrm{hrs}$. The dried leaves were then milled into powder with an electric blender.

Nail

The nails (3 inch nails) were also obtained from the building material shops at Ihiagwa market square.

\section{Cassava Sample}

Fresh harvested cassava (tuber) sample were peeled, washed and cut into small pieces of about $10 \mathrm{~g}$ each. About $200 \mathrm{~g}$ of each of the cassava was put into three (3) different plastic buckets. Five hundred milliliters (500ml) of tap water was added into the bucket containing the cassava sample.

The buckets were then labeled "A", "B" and "C", two pieces of 3 inches nails were dropped into bucket "A", $3 \mathrm{~g}$ of dried scent leaf was added into "B" and "C" was used as control (containing no additives). The set ups were allowed to undergo fermentation for four (4) days, at this period microbial analysis was also carried out daily on the steep water. 


\section{Microbial Analysis Of Steep Water}

Ten-fold serial dilution of each of the steep water in each day of fermentation was made using sterile water in ten tubes. This was done by placing $9 \mathrm{ml}$ of sterile water in each of the six test tubes and with the help of a sterile pipette, $1 \mathrm{ml}$ of the sample was collected and placed in the first tube till the last tube while homogenizing the contents.

After the serial dilution, $0.1 \mathrm{ml}$ of the $10^{-4}$ dilution of the steep sample was inoculated onto sterile plate of nutrient agar and potatoes dextrose agar. Nutrient agar was incubated at $37^{\circ} \mathrm{c}$ for $24 \mathrm{hrs}$, then potatoes dextrose agar was incubated under room temperature for $48 \mathrm{hrs}$.

At the conclusion of the incubation period, the plates were examined for microbial growth and the colonies found were counted and characterized using gram staining and biochemical test for the bacterial isolates while the fungal isolates were identified using morphological characteristics and lactophenol cotton blue staining technique. These procedures were repeated each day of fermentation for the 3 set ups.

\section{1dentification of Bacterial Isolates}

The bacterial isolates from the plate were identified by morphological appearance, gram staining and biochemical tests such as motility test, coagulase test, catalase test, indole test, oxidase test and Lactophenol Cotton Blue Staining Techniques using Bergey's manual of determinative bacteriology.

\section{Physiochemical Parameters pH Determination}

About $20 \mathrm{ml}$ of buffer solution was poured into a clean $50 \mathrm{ml}$ Polypropylene beaker. The electrode of a stabilized $\mathrm{pH}$ meter was immersed into the buffer solution and the temperature adjusted. Thereafter, 20ml of the sample was poured into the beaker and gently stirred. Finally, the $\mathrm{pH}$ of the sample was read directly from $\mathrm{pH}$ meter and the result recorded.

\section{Determination of Cyanide Content of the Samples:}

The Grignard test used by (Tivana, 2012) was utilized. Twenty (20ml) milliliters of the filtered fermenting cassava water was pipetted into a $100 \mathrm{ml}$ conical flask and $10 \mathrm{ml}$ of alkaline sodium picrate solution added and mixed.

Ten milliliters of the mixture were transferred into test tubes and incubated in a water bath at $94^{0} \mathrm{c}$, for $5 \mathrm{minutes}$ and allowed to cool at room temperature. Absorbance of the mixture was read from a spectrum lab 755s UV-VIS spectrophotometer at $540 \mathrm{~mm}$ and recorded as the average of three readings.

\section{Calculation:}

The cyanide concentrations of the samples were determined from potassium cyanide standard curve (already prepared).

\section{Proximate Analysis}

\section{Determination of Fibre Content:}

The dried sample $(2 \mathrm{~g})$ was weighed in the fibre flask, $100 \mathrm{ml}$ of $0.25 \mathrm{NH}_{2} \mathrm{~S}_{4}$ was added and the sample boiled for $1 \mathrm{hr}$. The heated mixture was filtered, the filtrate obtained discarded and the residue was returned to the fibre flask to which $100 \mathrm{ml}$ of $0.31 \mathrm{M} \mathrm{NaOH}$ was added and heated under reflux for another $1 \mathrm{hr}$. The mixture was filtered and $10 \mathrm{ml}$ of acetone introduced to dissolve any organic constituent. The residue was then washed twice on the sieve cloth with $50 \mathrm{ml}$ hot water before it was used.

The mixture was finally transferred into the crucible. The crucible and the residue was oven dried at $105^{\circ} \mathrm{C}$ overnight to drive off moisture.

The oven dried crucible containing the residue was cooled in a dessicator and afterwards weighed to obtain the weight $\mathrm{W}_{1}$. The crucible weight $\left(\mathrm{W}_{1}\right)$ was transferred to the muffle furnace (Box-type resistance furnace $\left.5 \mathrm{x}-5-12\right)$ for ashing at $50^{\circ} \mathrm{C}$ for $48 \mathrm{hrs}$. The crucible containing white or grey ash was cooled in the desiccators and weighed to obtain $\mathrm{W}_{2}$. The difference $\mathrm{W}_{1^{-}} \mathrm{W}_{2}$ gives the weight of fibre (AOAC, 1990). 
The percentage fibre was obtained by the formula:

$\%$ fibre $=\frac{\mathrm{w}_{1}-\mathrm{w}_{2}}{\text { weightofsample }} \times \frac{100}{1}$

\section{Determination of Moisture Content:}

About $10 \mathrm{~g}$ of the sample was put into a pre-weighed, pre-dried and cooled crucible and dried in the oven at $105^{\circ}$ for $2 \mathrm{hrs}$ until constant weight was obtained.

\section{Calculation:}

$\%$ moisture $=\frac{\mathrm{w}_{2}-\mathrm{w}_{3}}{\mathrm{w}_{2}-\mathrm{w}_{2}} \times \frac{100}{1}$

Where;

$\mathrm{w}_{1}=$ initial weight of empty crucible

$\mathrm{W}_{2}=$ weight of crucible and sample before drying

$\mathrm{W}_{3}=$ final weight of crucible and sample after drying.

\section{Determination of Ash Content:}

Empty crucibles were transferred to the muffle furnace to burn off all organic matter and to stabilize the weight of the crucible at the temperature range of $550-600^{\circ} \mathrm{C}$ before cooling to room temperature in a desiccator.

About $5 \mathrm{~g}$ of finely ground sample was poured into the pre-weighed crucible and transferred into a pre-heated furnace and ashed for $3 \mathrm{hrs}$ at $600^{\circ} \mathrm{C}$. The crucible and its content (ash) were cooled in a desiccator and re-weighed.

\section{Calculation:}

$$
\begin{aligned}
\% \text { Ash }= & \frac{\text { weightof Ash }}{\text { weightsample }} \times \frac{100}{1} \\
& =\frac{w_{3}-w_{1}}{w_{2}-w_{1}} x \frac{100}{1}
\end{aligned}
$$

$\mathrm{w}_{1}=$ Weight of empty crucible

$\mathrm{W}_{2}=$ Weight of crucible and sample before ashing

$\mathrm{W}_{3}=$ Weight of crucible and ash.

\section{Determination of Crude Protein Content:}

Kjeldahl method was used for determination of crude protein, exactly $8 \mathrm{~g}$ of the sample and $3 \mathrm{~g}$ of copper sulphate catalyst and $25 \mathrm{ml}$ of concentrated sulphuric acid was heated over a bursen flame in a fume cupboard. It was then heated with shaking intervals for $1 \mathrm{hrs}$ until the mixture became clear.

About $400 \mathrm{ml}$ of distilled water was added followed by the addition of $50 \mathrm{ml}$ of $20 \%$ boric acid with $1 \mathrm{ml}$ methyl red indicator; $75 \mathrm{ml}$ of $50 \% \mathrm{NaOH}$ was added to make the solution alkaline. The ammonia was distilled into the boric acid solution. $250 \mathrm{ml}$ of the distillate was collected after washing the walls of the receiver and the condenser. The distillate was titrated with $0.1 \mathrm{~N}$ sulphuric acid. The percentage crude protein was calculated from the percentage nitrogen of the sample as follows;

$\%$ Nitrogen $=\frac{\text { vol. of acid-conc. of acid) } \times 1.4}{\text { weightof sample }}$

Therefore, $\%$ crude protein $=\%$ Nitrogen $\times 6.25$.

Total Available Carbohydrate :

Calculation:

$\%$ ash + crude protein + moisture + crude fibre $=x$

$\%$ carbohydrate $=100-\mathrm{x}$. 


\section{Results:-}

\section{Additives:}

Nail and scent leaves were used to ferment cassava roots. Table 1 presents the daily microbial load of the fermenting steep of the cassava samples for four days. Table 2 shows the result for the identification of the bacteria isolates while table 3 shows the result for the identification of the fungal isolates.

Table 4 and 5 present the daily $\mathrm{pH}$ and cyanide content of the fermenting cassava water respectively. Table 6 present the results on proximate analysis of the fermenting cassava.

Table 1:-Microbial load of the steep sample for a period of four days

\begin{tabular}{|l|l|l|l|}
\hline Sample & Days & $\begin{array}{l}\text { Fungal } \\
(\mathbf{x 1 0} \mathbf{c f u} / \mathbf{m l})\end{array}$ & $\begin{array}{l}\text { Total Viable Bacterial } \\
\text { Count }(\mathbf{x 1 0} \mathbf{c f u} / \mathbf{m l})\end{array}$ \\
\hline $\mathrm{A}$ & 1 & 1.0 & 1.7 \\
& 2 & 1.4 & 3.0 \\
& 3 & 2.4 & 3.6 \\
\hline B & 4 & 3.0 & 3.8 \\
& 1 & 1.0 & 1.5 \\
& 2 & 1.7 & 3.0 \\
\hline C & 3 & 2.4 & 3.5 \\
& 4 & 3.1 & 3.8 \\
\hline & 1 & 1.0 & 1.4 \\
& 2 & 1.6 & 1.9 \\
& 3 & 2.1 & 2.5 \\
\hline
\end{tabular}

Key:

$\mathrm{A}=$ Cassava sample with nail

$\mathrm{B}=$ Cassava sample with scent leaf

$\mathrm{C}=$ Control

Table 2:-Identification of the bacterial isolates

\begin{tabular}{|l|l|l|l|l|l|l|l|l|l|l|}
\hline mple & $\begin{array}{l}\text { Days of } \\
\text { Appearance }\end{array}$ & $\begin{array}{l}\text { Morphological } \\
\text { appearance }\end{array}$ & $\begin{array}{l}\text { Gram } \\
\text { staining }\end{array}$ & $\begin{array}{l}\text { Mot } \\
\text { test }\end{array}$ & $\begin{array}{l}\text { Oxi } \\
\text { test }\end{array}$ & $\begin{array}{l}\text { Ind } \\
\text { test }\end{array}$ & $\begin{array}{l}\text { Spore } \\
\text { stain }\end{array}$ & $\begin{array}{l}\text { Cat } \\
\text { test }\end{array}$ & $\begin{array}{l}\text { Coa } \\
\text { test }\end{array}$ & $\begin{array}{l}\text { Possible } \\
\text { bacteria }\end{array}$ \\
\hline A, B, C & $1,2,3,4$ & $\begin{array}{l}\text { Milkish raised } \\
\text { non-mucoid }\end{array}$ & + & - & - & - & - & - & - & $\begin{array}{l}\text { Streptococcus } \\
\text { spp }\end{array}$ \\
\hline A, B, C & 1,2 & $\begin{array}{l}\text { Cream, rough } \\
\text { and circular }\end{array}$ & + & - & - & - & + & + & - & Bacillus spp \\
\hline A and C & 1,2 & $\begin{array}{l}\text { Bluish-green } \\
\text { pigmented flat } \\
\text { colonies }\end{array}$ & - & + & + & - & - & + & - & $\begin{array}{l}\text { Pseudomonas } \\
\text { spp }\end{array}$ \\
\hline A and C & 1 & $\begin{array}{l}\text { Milkish } \\
\text { enlongated } \\
\text { non-mucoid } \\
\text { colonies }\end{array}$ & - & + & - & - & - & - & + & Proteus spp \\
\hline A, B, C & $2,3,4$ & $\begin{array}{l}\text { Gray to white } \\
\text { on TJA }\end{array}$ & + & - & - & - & + & - & - & $\begin{array}{l}\text { Lactobacillus } \\
\text { spp }\end{array}$ \\
\hline
\end{tabular}

Key:

$$
\begin{aligned}
& \text { Mot }=\text { motility } \\
& \text { coa }=\text { coagulase } \\
& \text { ind }=\text { indole } \\
& \begin{array}{l}
\text { Oxi }=\text { oxidase } \\
\text { cat }=\text { catalase } \quad+=\text { positive result } \quad-=\text { negative result }
\end{array}
\end{aligned}
$$


Table 3:-Identification of the fungal isolates

\begin{tabular}{|l|l|l|l|l|}
\hline Sample & $\begin{array}{l}\text { Days of } \\
\text { Appearance }\end{array}$ & Colony Characterizes & Cell Morphology & Possible Fungi \\
\hline A, B, and C & $1,2,3,4$ & Whitish raised colony & $\begin{array}{l}\text { Double branching } \\
\text { septate hyphae }\end{array}$ & Aspergillus spp \\
\hline A, B and C & $2,3,4$ & $\begin{array}{l}\text { Cream white and } \\
\text { smooth }\end{array}$ & $\begin{array}{l}\text { Budding cells and } \\
\text { pseudo-hyphae }\end{array}$ & Candida spp \\
\hline A, B, C & 3,4 & $\begin{array}{l}\text { Smooth cream and } \\
\text { white }\end{array}$ & Budding cells & Saccharomyces spp \\
\hline
\end{tabular}

Table 4:-pH values of the fermenting samples

\begin{tabular}{|l|l|l|l|}
\hline $\begin{array}{l}\text { Samples } \\
\text { Days }\end{array}$ & A & B & C \\
\hline 1 & 7.24 & 7.16 & 7.26 \\
\hline 2 & 6.90 & 6.97 & 6.95 \\
\hline 3 & 5.72 & 6.10 & 6.20 \\
\hline 4 & 4.99 & 5.75 & 5.77 \\
\hline
\end{tabular}

ykeys:

$\mathrm{A}=$ Sample with nail

$\mathrm{B}=$ Sample with scent leaf

$\mathrm{C}=$ Control

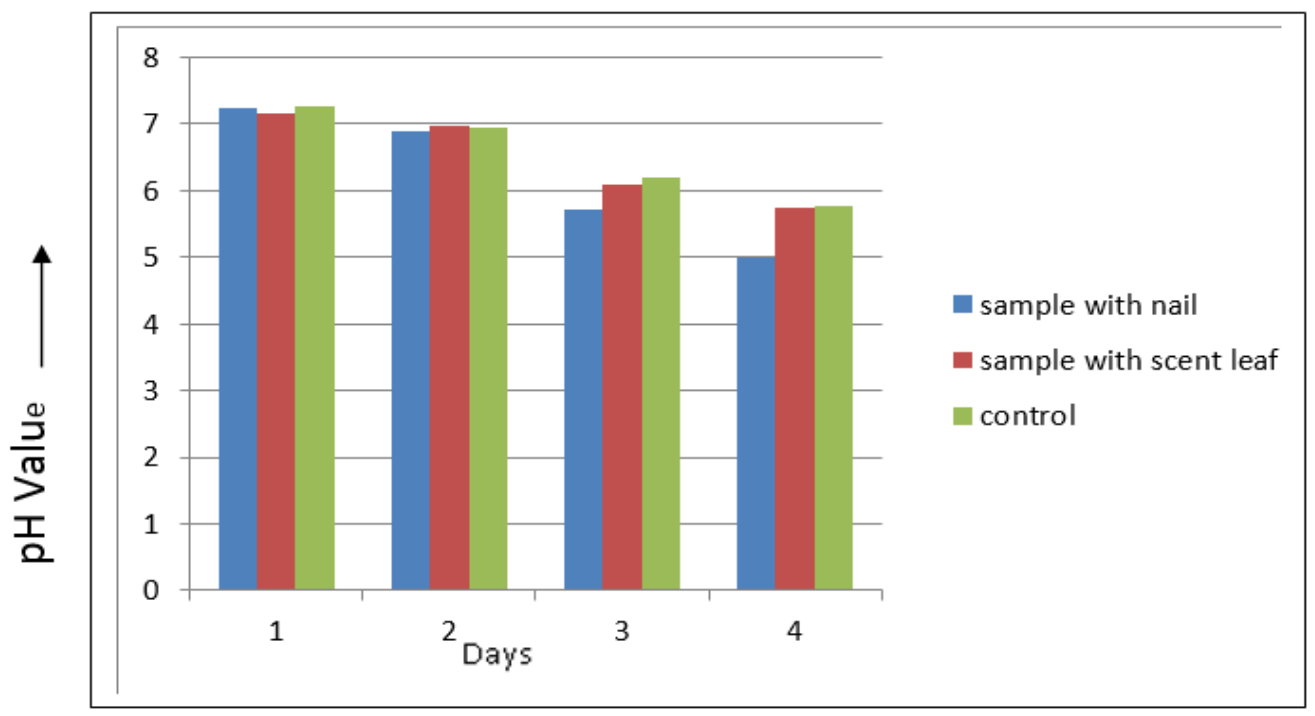

Fig 5: $\mathrm{pH}$ values of the fermenting sample

Table 5:-Cyanide content of fermenting cassava water $(\mathrm{mg} / \mathrm{ml})$

\begin{tabular}{|l|l|l|l|}
\hline $\begin{array}{l}\text { Samples } \\
\text { Days }\end{array}$ & A & B & C \\
\hline 1 & 0.31 & 0.28 & 0.27 \\
\hline 2 & 1.36 & 1.35 & 0.79 \\
\hline 3 & 2.50 & 2.44 & 1.10 \\
\hline 4 & 3.40 & 3.02 & 1.33 \\
\hline
\end{tabular}

keys:

$A=$ Sample with nail

$\mathrm{B}=$ Sample with scent leaf 


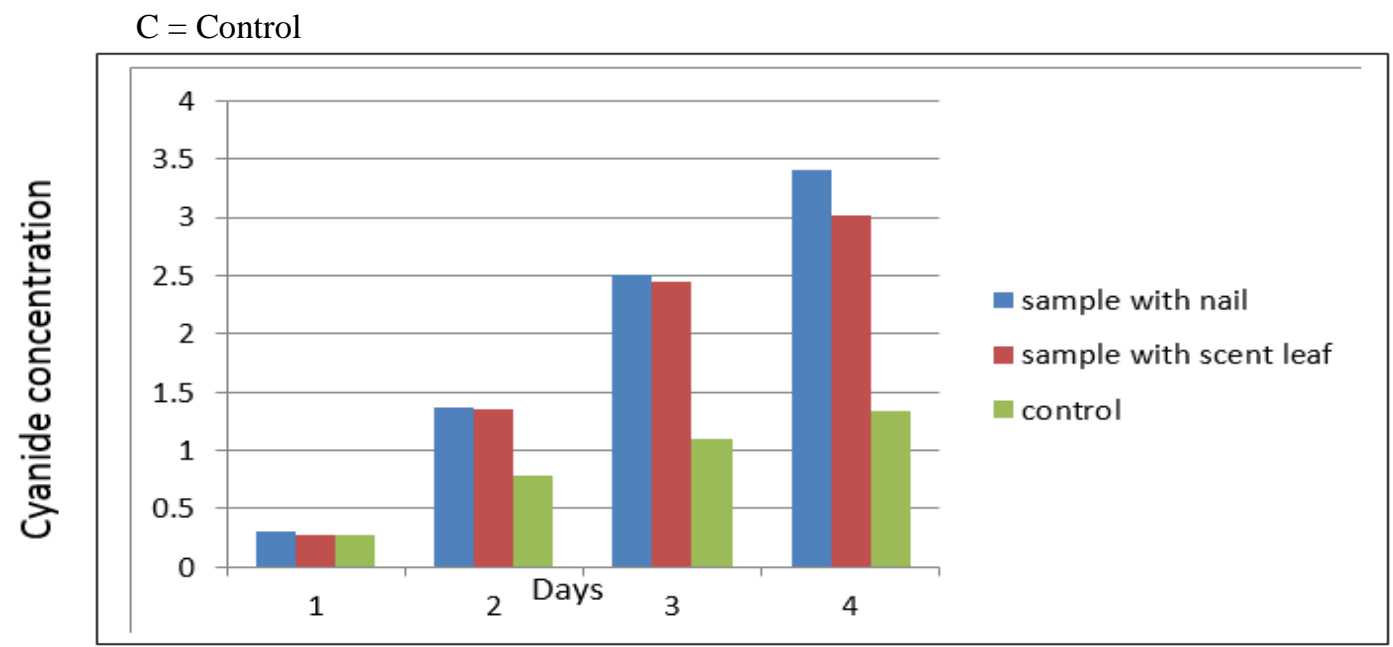

Fig 6:-Cyanide content of the fermenting cassava water $(\mathrm{mg} / \mathrm{ml})$

Table 6:-Proximate analysis of the fermented cassava samples

\begin{tabular}{|l|l|l|l|l|}
\hline Days & Contents & \multicolumn{2}{|l|}{ Additives } & \multirow{2}{*}{ Control (\%) } \\
\cline { 3 - 4 } & & Nail (\%) & Scent leaf (\%) & \\
\hline 1 & Ash & 2.40 & 3.20 & 2.00 \\
& Fibre & 9.50 & 10.00 & 8.50 \\
& Moisture & 8.95 & 10.83 & 10.91 \\
& Protein & 2.45 & 5.95 & 3.22 \\
& Carbohydrate & 76.70 & 70.02 & 75.37 \\
\hline 4 & Ash & 1.80 & 1.60 & 6.30 \\
& Fibre & 5.00 & 13.00 & 7.00 \\
& Moisture & 10.55 & 9.91 & 12.36 \\
& Protein & 2.40 & 5.22 & 3.37 \\
& Carbohydrate & 80.25 & 70.27 & 70.97 \\
\hline
\end{tabular}

\section{Discussion:-}

The result presented in table 1 showed the microbial load (bacterial count and fungal count) of the steep water of both the control and the enhanced fermenting cassava. All the samples microbial counts increased daily, in line with the findings of (Umeh and Odido, 2014). It was observed that the total bacterial count of the enhanced fermented cassava was higher than the control. The cassava sample co-fermented with nail increased from $1.7 \times 10^{6}$ to $3.8 \times 10^{6}$ $\mathrm{cfu} / \mathrm{ml}$, the one co-fermented with scent leaf also increased from $1.5 \times 10^{6}$ to $3.8 \times 10^{6} \mathrm{cfu} / \mathrm{ml}$, while the control increased from $1.4 \times 10^{6}$ to $2.9 \times 10^{6} \mathrm{cfu} / \mathrm{ml}$. Total fungal counts of the enhanced cassava was also higher than the control. The nail co-fermented sample increased from $1.0 \times 10^{6}$ to $3.0 \times 10^{6} \mathrm{cfu} / \mathrm{ml}$, the sample co-fermented with scent leaf also increased from $1.0 \times 10^{6}$ to $3.1 \times 10^{6} \mathrm{cfu} / \mathrm{ml}$, while the control increased from $1.0 \times 10^{6}$ to $2.6 \times 10^{6} \mathrm{cfu} / \mathrm{ml}$. The high counts of the enhanced cassava against control may be because the additives provided an appropriate environment for the microorganisms to thrive. Metals (nails) are known to act as electrophonic catalysts.

The bacteria isolates encountered in the control were Streptococcus spp, Bacillus spp, Pseudomonas spp, Proetus spp and Lactobacillus spp. These same bacterial isolates were obtained from the fermentation steep of the additives except Pseudomonas spp and Proteus spp which were absent in the sample co-fermented with scent leaf. Their absence could be attributed to the inhibitory effects of scent leaf. Similar results of inhibition of some bacterial isolates involved in fermentation by other fermentation enhancing substance have been reported by Aisien, (2007). A microbial succession trend was found with the starch degrading Bacillus spp, giving way to lactic acid bacteria and yeast that dominate the later part of the fermentation; this is in accordance with the report of Oyewole (1991). The fungal isolates are Aspergillus spp, Candida spp and Saccharomyces spp presented in Table 3, the presence of Saccharomyces spp indicates its important role in root detoxification, as already reported by Oboh \& Akindahunsi (2003). The result in table 2 and 3, confirm the results of researches by Oyewole (1991) and Umeh \& Odido (2014), showing the importance of microbial growth for efficient elimination of cyanogens. 
The $\mathrm{pH}$ of the fermenting water decreased as fermentation advanced, tending towards acidity. This corroborates with the findings of Umeh \& Odido (2014) and Salami et al., (2011) where the use of additives affected pH rate, with different additives having its specific rate decrease. The use of nail showed the fastest decrease rate from 7.24 to 4.99, the use of scent leaf decreased from 7.16 to 5.75 and the control from 7.26 to 5.77 Oyewole (1991) reported that the fermenting roots acidic condition supported the prevalence of bacteria action needed for hydrolysis. Therefore, diminishing $\mathrm{pH}$ indicates microbial growth which affects cassava tuber hydrolysis and indicates that fermentation occurred. The acidity was increasing while $\mathrm{pH}$ was decreasing, as reported by Salami et al., (2011) and Umeh \& Odido (2014). So decrease in $\mathrm{pH}$ is followed by a corresponding increase in the acidity means fermentation increased.

The cyanide content of the fermenting water went up as fermentation progressed, showed that the cyanide in the roots was released in the retting water for the roots to detoxify. This corresponded with the findings of Umeh \& Odido (2014) that during cassava roots fermentation, the fermenting water turns acidic with high cyanide content, while the roots tend towards alkaline with low cyanide. The fermenting water with additives had higher cyanide content than the control and nail showing the most effective in cassava detoxification.

The proximate analysis of the cassava showed that the percentage moisture content of the control sample was slightly higher than its corresponding cassava samples co-fermented with nail and scent leaf. The protein content of cassava co-fermented with nail was the least and sample co-fermented with scent leaf showed the highest. The protein content of cassava co-fermented with additives showed slight decrease between day 1 and 4 while control increase slightly. The ash content of control in day 1 was seen to be the lowest but became highest in day 4 , while the sample co-fermented with scent leaf was seen to be the highest in day 1 but became the lowest in day 4 . Hence, the ash content of the cassava with additives, showed a decrease between day 1 and 4 while the control tends to increase.

Furthermore, the fibre content of cassava co-fermented with scent leaf was the highest both in day 1 and 4 , while control was least in day land sample co-fermented with nail was low on day 4. The sample co-fermented with nail and control showed a decrease between day 1 and 4, while the sample co-fermented with scent leaf increased. The percentage content of carbohydrate in the sample co-fermented with nail has the highest with an increase between day 1 and 4 . The sample with scent leaf shows the least both in day 1 and 4 with little increase in day 4, showing no significant difference in the percentage carbohydrate content of control in day 4 due to its decrease from day 1.

Overall, the sample co-fermented with nail showed the highest carbohydrate content, the least protein content and had the fastest fermentation rate and detoxification effect. The sample with scent leaf showed the least carbohydrate content, the highest protein content and fermentation rate was slower than the one with nail but faster than the control.

\section{Conclusion:-}

This work has demonstrated that the fermentation of cassava is a product of hetero-fermentation by different microorganisms. The proliferation of those useful organisms in the fermenting steep may also have increased the fermentation process.

The course of this study has made it known that scent leaf enhances the detoxification of cassava root by removing the residual cyanide content in cassava, speed up the rate of retting of cassava roots as well as improve the protein content of fermented cassava than the nail and control.

\section{Recommendation:-}

Cassava can be processed while mixed with many micronutrient-rich vegetables. It is recommended that addition of scent leaf should be preferred to most of the traditional method of cassava fermentation processes. This is because of the benefit inherent in scent leaf in bringing about the desired effect in cassava fermentation.

\section{References:-}

1. Aisien, E. T. (2007). The Effects of Detergent on the Microbiological changes of fermenting cassava for fufu production. Advanced materials research, 18 (19): 143 
2. Aro, S. O. (2008). Improvement in the nutritive quality of cassava and its by-products through microbial fermentation. African Journal of Biotechnology, 7(25): 4789-4797.

3. Aworh, O. C. (2008). The role of traditional food processing technologies in national development: The West African experience. Chapter 3 from Using Food Science and Technology to Improve Nutrition and Promote National Development. Roberts G.L and Lipien J.R (Eds). International Union of Food Science and Technology pp; $1-18$.

4. Binin, M. E. (2014). Effects of microbial fermentation on the proximate, mineral and antinutritional constituents of selected varieties of cassava products. Dissertation school of postgraduate studies, Ahmadu Bello University, Zaria. Pp 1-358.

5. Egwim, E., Amanabo, M., Yahaya, A. and Bello, M. (2013). Nigerian Indigenous Fermented Foods: Processes and Prospects. Intech, 7:153-180.

6. Eleazu, C. O., Oti, E., Amajor, J. U., Ikpeama, A. I., Awa, E. and Eleazu, K. C (2011). Nutritional Evaluation and Microbial Load of Cassava (Manihot esculenta) sievates and peels fermented in Brine. International Journal of Advanced Scientific and Technical Research, 1(1):107-120.

7. Etudaiye, H. A., Nwabueze, T. U. and Sanni, L. O. (2009). Quality of fufu processed from cassava mosaic disease (CMD) resistant varieties. African Journal of Food Science, 3(3): 061 - 067.

8. Kobawila, S. C., Louembe, D., Keleke, S., Hownhouigan J. and Gamba C., (2005). Reduction of the content during fermentation of cassava roots and leaves to produce bikedi and ntoba mbodi, two food products from Congo. African Journal of Biotechnology, 4(7): 689-696.

9. Milena, L., Maria D. F., Arianna R. and Dante, M. F. (2013). Improved processing methods to reduce the total cyanide content of cassava roots from Burundi. African Journal of Biotechnology, 12(19): 2685-2691.

10. Montagnac, A. J., Davis, C. R. and Tanumihardjo, S. A. (2009). Processing techniques to reduce toxicity and anti-nutrient of cassava for use as a staple food. Comprehensive reviews in food science and food safety, 8: 1727.

11. Oboh, G. and Akindahunsi A. A. (2003). Biochemical changes in cassava product (flour and garri) subjected to Saccharomyces cerevisiae solid media fermentation. Journal of Food Chemistry, 82: 599-602.

12. Offor, C. E., Nweke, F. N., Okaka, A. C., Igwenyi, I. O. and Onwe, V. N. (2011). Analysis of the antinutrients levels in staple food crops in three different local government areas of Ebonyi State, Nigeria. Continental Journal of Food Science and Technology, 5(1): 26-30.

13. Oyewole, O.B., (1991). Cassava processing in Africa. National Research Council, National academy Press, Washington, D.C., pp:89-92.

14. Salami, L., Odunlami M.O., Adedeji A.O. and Olafadehan O.A., (2011). The synergistic effect at nail, linear Alkyl Benzene Sulphonate and trona on the rate of fermentation of cassava for "fufu". Int J. Applied Science and Technology, 1(3):22-27.

15. Sayre, R., Beeching, J. R., Cahoon, E. B., Egesi, C., Fauquet., Fellman, J., Fregene, M., Gruissemm, W., Mallowa, S., Manary, M., Mayiza-Dixon, B., Mbanaso, A., Schachtman, D. P., Salami, L., Odunlami M. O., Adedeji, A. O. and Olafadehan O. A. (2011). The synergistic effect at nail, linear Alkyl Benzene Sulphonate and trona on the rate of fermentation of cassava for "fufu". International Journal of Applied Science and Technology, 1(3):22-27.

16. Siritunga, D., Taylor, N., Vanderschuren, H. and Zhang, P. (2011). Biofortification of cassava for sub-saharan Africa: The BioCassava plus program. Annual Reviews in Plant Biology, 62: 251-272.

17. Tivana, L. D. (2012). Cassava processing: safety and protection fortification. Doctoral Thesis: 7-14.

18. Umeh, S. O. and Odido F. C. (2014). Use of different addition in retting cassava tubers for fufu production. International Journal of Pharmaceutical Science Invention, 3: 11-17. 